RESEARCH ARTICLE

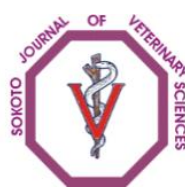

Sokoto Journal of Veterinary Sciences

(P-ISSN 1595-093X/ E-ISSN 2315-6201)

Suleiman et al/Sokoto Journal of Veterinary Sciences (2015) 13(1): 9-16.

http://dx.doi.org/10.4314/sokjvs.v13i1.2

\title{
Radiographic studies on morphological anomalies in artificially spawned Heterobranchus longifilis Valenciennes, 1840 F1 generation
}

\author{
B Suleiman $^{1 *}$, L Maruff $^{2} \&$ SJ Oniye ${ }^{3}$ \\ 1. Fisheries \& Biological Sciences, Ahmadu Bello University, Zaria, Nigeria \\ 2. Surgery and Radiology, Faculty of Veterinary Medicine, Ahmadu Bello University, Zaria-Nigeria \\ 3. Zoology \& Biological Sciences, Ahmadu Bello University, Zaria-Nigeria
}

*Correspondence: Tel.: +2348069675754, E-mail: aquablends@gmail.com

\begin{abstract}
This study was designed to examine radiographically the morphological anomalies in artificially spawned 24-weekold Heterobranchus longifilis. A total of 22 morphological deformities observed from an F1 population of 4,871 were classified. Based on anatomical positions, most of the anomalies (49.99\%) manifested in the bodies as stunted growth with a weight range of $240-358 \mathrm{~g}$, standard length (SL) of $18.7-29.1 \mathrm{~cm}$ and stump body trait with a weight range of $445-810 \mathrm{~g}$, SL of $22.9-35.9 \mathrm{~cm}$. Anomalies of the vertebral column accounted for $27.27 \%$ with a weight range of $410-945 \mathrm{~g}$, SL of $27.4-36.8 \mathrm{~cm}$. Fin aberrations including agenesis were seen in $22.73 \%$ with a weight range of $548-840 \mathrm{~g}$, SL of $34.1-39.2 \mathrm{~cm}$. Radiographic examination revealed anomalies such as hypoplasia and hyperplasia of fins, supernumeracry and agenesis of fins, fin cleft, and fusion of fins, scoliosis and kyphosis. The phenotypic lateral body curvatures and stump body trait were basically due to varying degrees and positions of scoliosis and thus, pathological. The fin aberrations and agenesis were probably congenital. The anomalies affected feed accessibility; thus; impaired the growth of the fishes evidenced by the low body weights recorded in the deformed fish compared to the normal fish. In conclusion, the percentage of morphological aberrations observed in the F1 population is negligible $(0.45 \%)$, thus it will not adversely affect production of $H$. longifilis via artificial induction.
\end{abstract}

Keywords: Artificial induction, Heterobranchus longifilis, Morphological anomalies, Radiography

Received: 01-08-2014

Accepted: 11-12-2014

\section{Introduction}

Aquaculture in Nigeria is limited by several constraints which include lack of and poor management of broodstocks, lack of sufficient healthy fingerlings, inadequate quality control regulation and standardization of the entire seed production chain and poor networking among stakeholders (Atanda, 2007). Among the culturable food fish in Nigeria, catfish is the most sought after, it is very popular with fish farmers and consumers, and commands a very good value in Nigerian markets (Oladosu et al., 1993). Irrespective of the breakthrough reported for artificial propagation of catfish (Madu et al., 1989), the demand for its seed outstrips the supply. The numerous potentials of the aquaculture industry are threatened by inadequate fish seed needed for production (Owodeinde et al., 2011). In the face of its popularity, the culture of catfish is unfortunately bedeviled with the problem of high mortality at the young stages and scarcity of good quality seeds (Adewumi et al., 2005). In some cases, due to high demand of widely acceptable species of catfish such as Heterobranchus longifilis and Clarias species, fingerlings of poor genetic quality are sold to farmers resulting in stunted 
growth of fish, poor survival rates, and poor returns on investment.

Clarias gariepinus and Heterobranchus longifilis are two commonly cultured clariid fishes very popular among fish farmers and consumers alike. They are reared all over the country especially in the south and have very good commercial value in Nigerian market (Adewolu \& Adoti, 2010). Qualities which make them suitable for culture include fast growth rate, high yield potential, fecundity and palatability (Offem et al., 2008). Heterobranchus and Clarias are two of the more than 300 species of fin fishes that have been cultivated but do not spawn easily in captivity (Brain \& Amy, 1980) necessitating artificial induction for mass production. Ovaprim is one of the most widely acceptable readily available synthetic hormones because it has been found to be very effective for spawning induction to get quality seed. It is a combination of SGnRHa (salmon gonadotrophin releasing hormone analogue) and domperidone (Sahoo et al., 2005).

The fast growing potential amongst other qualities of $H$. longifilis has stimulated multidisciplinary research on this species by several authors focusing on ecology and behavior (Baras, 1999), growth (Legendre et al., 1992), hybridization (Ataguba et al., 2009), inducing agents (Olubiyi et al., 2005), meristics (Legendre et al., 1992), morphology (Vandewalle et al., 1997), polyculture (Offem et al., 2009), reproductive behavior and reproductive cycle (Poncin et al., 2002), associated histological changes (Rodriguez et al., 1995), stocking density (Ovie et al., 2008), systematics (Teugels et al., 1992) and vitellogenesis (Rodriguez et al., 1995). Irrespective of these researches, there is paucity of information on certain cogent aspects such as the morphological anomalies in artificially spawned $H$. longifilis especially in Nigeria, which could invariably affect optimal productivity within systems.

This research is aimed at assessing the occurrence and types of morphological anomalies in artificially spawned $H$. longifilis $\mathrm{F} 1$ generation using radiography. $\mathrm{X}$-rays are a type of electromagnetic radiation produced by the collision of high energy particles with other charged particles. The speed of passage of the radiation through a body depends on density, with relatively dense materials like bones yielding white images (Netting, 2007).

\section{Materials and Methods}

\section{Induced breeding}

Induced breeding activities were carried out in the rainy season in July, 2012 following recommended and widely used methods as described by De Graaf \& Janssen (1996). Triplicate crosses, each consisting of 2 females and a male of morphometrically similar broodfish from the same genetic pool were carried out. The synthetic hormone ovaprim was administered intramuscularly at the rate of $0.5 \mathrm{ml} / \mathrm{kg}$. Breeding and physicochemical indices were noted. Fishes were raised within built-up concrete ponds in a water recirculation system. They were fed decysted artemia and various pellet sizes of the durante superior fish concentrate basically containing $45 \%$ crude protein. The growth and survival rates of the F1 generation were calculated following recommended methods of Madu et al. (2003) and Fagbenro \& Sydenham (1988) respectively.

\section{Observance of deformed fishes}

At the end of the 24-week culture period, all the fish samples were harvested, morphologically deformed fishes were identified, counted, had their morphometrics taken and kept for further studies. The deformed fishes had their standard and total lengths taken with the aid of a measuring board (to the nearest $0.1 \mathrm{~cm}$ ) and weights (to the nearest $0.1 \mathrm{~g}$ ) with the aid of a top loading balance (model: Gottinen V-240). The types and percentage occurrence of morphological aberration observed were noted. Deformed samples were subjected to Xray and skeletal radiographic images were captured.

\section{X-ray photography}

X-ray photographs were carried out within a 50-60 $\mathrm{Kv}$ range, in the X-ray Unit of the Department of Radiology and Surgery, Faculty of Veterinary Medicine, Ahmadu Bello University, Zaria, with the aid of a portable X-ray unit (Hiray Plus Model PORTA 100HF, Japan). Each batch of fish samples was placed on a photographic film on an x-ray tray, exposed to the X-ray lamp, via the use of laser pointers the optimal power and exposure time were selected within the 50-60 kV and 0.3-1.2 mA range respectively and radiographic images captured and processed. The processed films were viewed on an image viewer. All the manufacturer's instructions with respect to safety were adhered to (Eickemeyer, 2005). 


\section{Results}

Morphological anomalies

A range of anomalies were observed in the $H$. longifilis F1 and these were sustained up to the 24th week. Based on anatomical positions, most of the anomalies (49.99\%) manifested in the bodies as stunted growth with a weight range of $240-358 \mathrm{~g}$, standard length (SL) of $18.7-29.1 \mathrm{~cm}$ and stump body trait with a weight range of $445-810 \mathrm{~g}$, SL of 22.9$35.9 \mathrm{~cm}$. Anomalies of the vertebral column accounted for $27.27 \%$ with a weight range of 410 $945 \mathrm{~g}$, SL of $27.4-36.8 \mathrm{~cm}$. Fin aberrations were found in $22.73 \%$ with a weight range of $548-840 \mathrm{~g}$, SL of $34.1-39.2 \mathrm{~cm}$.
The morphological anomalies observed in $H$. longifilis $\mathrm{F} 1$ generation are recorded in Table 1 . The percentage of deformities and morphological aberrations was $0.45 \%$ of the total $H$. longifilis $\mathrm{F} 1$ population. Stumpy body is believed to be as a result of abdominal ossification of the trunk vertebrae. Deformed fish were shortened along the anterior posterior axis, more deep bodied with shortened trunk compared to a normal fish.

Radiographs of deformed Heterobranchus longifilis The observed anomalies are recorded in Table 2 and some photographs of lateral body curvatures and fin anomaly are shown below (Plates I and II).

Table 1: Occurrence of Morphological Aberrations in 24-week Heterobranchus longifilis F1

\begin{tabular}{|c|c|c|c|c|c|}
\hline \multirow{2}{*}{$\begin{array}{l}\text { Morphological } \\
\text { Aberration } \\
\text { Stunted Growth }\end{array}$} & \multirow{2}{*}{$\begin{array}{l}\text { Brief Description } \\
\text { Glaring small size }\end{array}$} & \multicolumn{2}{|c|}{ Morphometrics } & \multirow{2}{*}{$\begin{array}{c}\text { Occurrence } \\
5\end{array}$} & \multirow{2}{*}{$\begin{array}{l}\text { Prevalence } \\
(\%) \\
0.10\end{array}$} \\
\hline & & wt & $240-358 g$ & & \\
\hline & & $s L$ & $18.7-29.1 \mathrm{~cm}$ & & \\
\hline & & TL & $23.1-26.3 \mathrm{~cm}$ & & \\
\hline \multirow[t]{3}{*}{ Stump Body } & $\begin{array}{l}\text { Anterior protrusion of muscle mass } \\
\text { posterior to head region }\end{array}$ & wt & $345-810 \mathrm{~g}$ & 6 & 0.12 \\
\hline & & sL & $18.7-29.1 \mathrm{~cm}$ & & \\
\hline & & $\mathrm{TL}$ & $26.5-41.4 \mathrm{~cm}$ & & \\
\hline \multirow{5}{*}{$\begin{array}{l}\text { Lateral } \\
\text { Curvatures }\end{array}$} & Laterally deviated body shapes; & wt & $410-945 g$ & 6 & 0.12 \\
\hline & throughout body length (4 specimens) & & & & \\
\hline & $\begin{array}{l}\text { and towards caudal peduncle ( } 2 \\
\text { specimens) }\end{array}$ & & & & \\
\hline & & SL & $27.4-36.8 \mathrm{~cm}$ & & \\
\hline & & $\mathrm{TL}$ & $32.5-43.1 \mathrm{~cm}$ & & \\
\hline \multirow[t]{4}{*}{ Fin Aberrations } & Split dorsal fin & wt & Weight & 4 & 0.08 \\
\hline & (1 specimen) & & $548-840 g$ & & \\
\hline & Fused dorsal and anal fins ( 2 specimens) & & & & \\
\hline & $\begin{array}{l}\text { Split right pelvic fin } \\
\text { (1 specimen) }\end{array}$ & & & & \\
\hline $\mathrm{Wt}$ - weight & & & & & \\
\hline & & & & & \\
\hline TL - Total lenght & & & & & \\
\hline
\end{tabular}


Table 2: Radiographic Anomalies Observed in 24-week Heterobranchus longifilis F1

\begin{tabular}{ll}
\hline Body Part & Radiographic Diagnosis (Occurrence) \\
\hline Head & Lateral deviation of the turbinate bone (1) \\
Vertebral Column & a) Scoliosis of proximal $1 / 3^{\text {rd }}(3)$ \\
& b) Scoliosis of midpoint (2) \\
& c) Scoliosis of distal $1 / 3^{\text {rd }}(3)$ \\
& d) Kyphosis (1) \\
\hline Fins & a) Agenesis of pectoral fin (1) \\
& b) Hypoplasia of pectoral fin (2) \\
& c) Hyperplasia of pectoral fin (1) \\
& d) Splitting of pelvic fin (1) \\
& e) Extension of dorsal fin beyond the dorsum (1) \\
& f) Fusion of dorsal and anal fins (1) \\
\hline
\end{tabular}

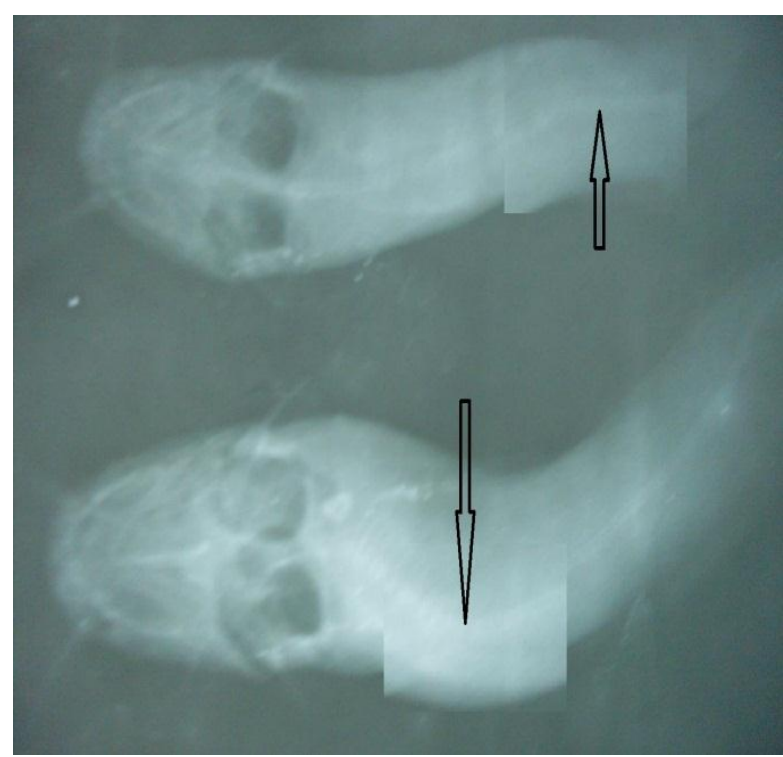

Plate I: Dorso-ventral view of skeletal image in laterally curved Heterobranchus longifilis

Diagnosis: Marked cranial scoliosis with a mild caudal scoliosis

\section{Discussion}

Vertebral deformities like scoliosis (lateral flexures; abnormal lateral curvature), lordosis (dorso-ventral flexures; excessive inward curvature), kyphosis (backward spinal curvature; excessive outward curvature), though rare, have been recorded for many species of teleosts. These deformities in larvae are mostly originated due to poor egg quality of female (Makeeva \& Saha, 1985), environmental conditions where eggs are incubated (KorwinKossakowski, 1988), pesticide or heavy metal

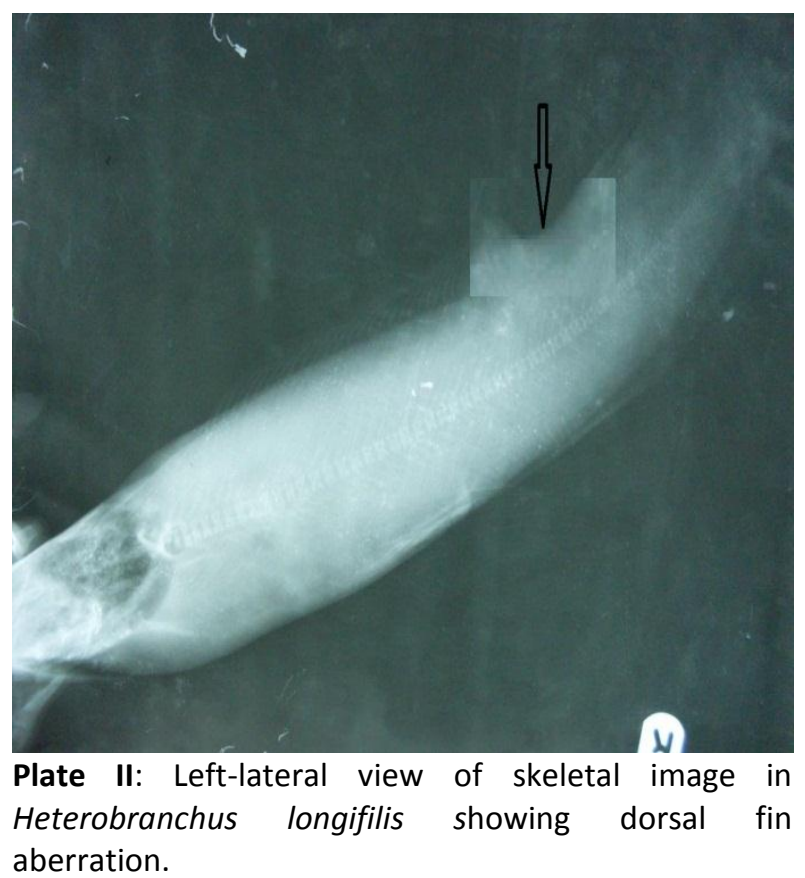

Diagnosis: Congenital hyperplasia of the dorsal fin with a cleft at the caudal $1 / 3$ rd region

exposure and fertilization of over-riped eggs in delayed stripping of ovulated eggs (Richter \& Vander Hurk, 1982). Other causes of these have been ascribed to scarcity of nutrients, oxygen deficiency, sudden changes in temperature, water current, mutation, inbreeding, parasitic infestation, mechanical trauma and attack from predators (Fagbuaro, 2009).

The aforementioned cases could not have accounted for the deformities in this study as induced spawning 
was carried out in a controlled environment under optimal conditions with the exception of mechanical trauma, associated with the recirculation system. The latency period in this study fell within the recommended range for $H$. longifilis thus could not have significantly influenced the percentage of deformed larvae. Increased latency period beyond $17 \mathrm{hr}$ led to significant increase in percentage of deformed larvae (11\%) of C. batrachus (Sahoo et al., 2005).

In this study the X-ray revealed that the stump body was actually attributable to marked cranial scoliosis. The skeletal abnormalities, in particular scoliosis and kyphosis observed in this study, probably have no genetic basis and could likely have resulted from environmentally induced congenital defects as reported by Dunham et al. (1991) for channel catfish Ictalurus punctatus; and by Castro et al. (2008) for the gilt head sea bream. A possible environmental stress factor could be the flow rate within the recirculation system on the larvae as malformation of vertebrae sometimes resulted from severe curvature of the vertebral column from poor balance of lateral muscles (Komada \& Moyer, 1983). Some authors had discussed the possible association of the skeletal deformities and environmental stress (Boglione et al., 2006).

In this study, though the fishes were fed vitamin $C$ inclusion diets, the unstable nature of vitamin $C$ in water could have led to its dissolution from some of the feed. The effect of this deficiency is compounded by the fact that fish, unlike other animals, cannot make their own vitamin C due to lack of gulonolactone oxidase responsible for the synthesis of vitamin $C$ in $H$. longifilis's liver and kidney (Dabrowski, 2001). Deformities primarily scoliosis and lordosis with depigmented areas on backs apparent at and above 12 weeks (100 to 180g) of channel catfish were reported by Lovell (1973) as being associated with vitamin $C$ deficiency. The recirculating experimental system used is more stressful and may require a higher amount of vitamin $C$ than those reared in a flow-through system used in some other experiments (Wang et al., 2002).

Vitamin C is an essential co-enzyme in certain oxidative processes, such as the oxidation of tyrosine and phenylalanine (Brander \& Pugh, 1977); this dictates for higher weight gain and whole body crude protein content. Previous study revealed that inclusion of $50 \mathrm{mg}$ vitamin C kg-1 forestalled deformities. The importance of vitamin $C$ has also been indicated in the proper development and functioning of the gills (Muir, 1984).

Wilson \& Poe (1973) observed major pathological conditions; altered pigmentation, lordosis, scoliosis and ultimately, a broken back in scorbutic conditioned catfish. These authors concluded that these pathological conditions were due to impaired collagen biosynthesis due to the absence of dietary ascorbic acid. Furthermore, the skeletal deformities (lordosis and scoliosis) are symptoms of broken head disease evidenced by lateral crack in skull observed in fish $>10 \mathrm{~cm}$ and treated by providing supplementary vitamin $C$ in feeds (FAO, 2012).

The occasional occurrence of fin aberrations corroborates the findings of Akinwade (2011). Although the author attributed these to environmental effects, photo-graphic X-ray revealed that the supernumerary pectoral fin aberration observed in this study was at the base of its root thus probably a congenital anomaly. The results obtained in this study with respect to fin aberrations, are in tandem with the findings of Aluko et al. (2001) who stated that most of the nine aberration types they observed were recorded in the Clarias $x$ Clarias group than in hybrids; these included absence of left pectoral fin, rudimentary pectoral fin and curved posterior dorsal fin. They concluded that the level of aberrations indicates the involvement of genotypic rather than environmental effects.

The percentage of morphological aberrations observed is negligible (0.45\%) compared to the $75 \%$ observed in a cross between $C$. gariepinus and $H$. longifilis (Aluko et al., 2001), and the $81 \%$ observed in the European bass by Chatain (1994). The fish samples under study were not analyzed genetically hence it could not be ascertained whether the anomalies were hereditary or not, but the negligible percentage occurrence suggest otherwise. High levels of deformities existing in different age classes could be a sign of significant ecosystem changes or genetic changes of population (Fagbuaro \& Oso, 2011).

In some species, the deformed fish does not live to grow old but in this species deformed ones survived up to the end of the experimental period. Vertebral deformities may affect the biology of the affected fish indirectly through inhibiting its free movement (Jawad, 2004). Deformed fish have been noted to increase production costs, as they require manual sorting, and lower performances (i.e. swimming ability, conversion index, growth rate, survival, and susceptibility to stress and pathogens) (Boglione et al., 2001). 
In conclusion, the percentage of deformities and morphological aberrations was $0.45 \%$ of the total $H$. longifilis F1 population (4,871). Various anomalies were recorded; stunted growth, varying degrees of scoliosis, kyphosis, hypoplasia, hyperplasia, supernumerary fins and congenital fusion of fins most probably of congenital and pathological bases. The fish samples studied were not analyzed genetically hence it could not be ascertained

\section{References}

Adewolu MA \& Adoti AJ (2010). Effect of mixed feeding schedules with varying dietary crude protein levels on the growth and feed utilization of Clarias gariepinus (Burchell, 1822) fingerlings. Journal of Fisheries and Aquatic Science, 5(4): 304-310.

Adewunmi AA, Olaleye VF \& Adesulu EA (2005). Egg and sperm quality of the African catfish, Clarias gariepinus (Burchell) broodstock fed differently heated soyabean-based diets. Research Journal of Agriculture and Biological Sciences, 1(1): 17-22.

Akinwade A (2011). Cytogenetic and electrophoretic studies on interspecific and intergeneric hybridization of Clariid Catfishes, Heterobranchus and Clarias species. Unpublished PhD dissertation, Department of Fisheries and Aquaculture Technology, Federeal University of Technology, Akure Nigeria. Pp 1-190.

Aluko PO, Awopetu JI \& Adeola AO (2001). Genetic basis for pectoral fin deformities in the African catfish Clarias gariepinus (Burchell, 1822), Heterobranchus longifilis (Valenciennes, 1840) and their hybrids. Aquaculture Research, 32(1): 21-27.

Ataguba GA, Annune PA \& Ogbe FG (2009). Induced breeding and early growth progeny from crosses between two African clariid fishes, Clarias gariepinus (Burchell) and Heterobranchus longifilis under hatchery conditions. Journal of Applied Biosciences, 14(1): 755-760.

Atanda AN (2007). Freshwater fish seed resources in Nigeria. In: Assessment of Freshwater Fish Seed Resources for Sustainable Aquaculture (Bondad-Reantaso, MG editor). FAO Fisheries Technical Paper. No. 501. Pp 628.

Baras E (1999). Sibling cannibalism among juvenile vundu under controlled conditions. Cannibalistic behavior, prey selection weather the anomalies were hereditary or nonhereditable.

\section{Acknowledgement}

The technical expertise of Mr. Mubarak Ali of the Department of Radiology and Surgery, Faculty of Veterinary Medicine, Ahmadu Bello University, Zaria is appreciated.

and prey size selectivity. Journal of Fish Biology, 54(1): 82-105.

Boglione C, Costa C, Giganti M, Cecchetti M, Di Dato P, Scardi M \& Cataudella S (2006). Biological monitoring of wild thick lip grey mullet (Chelon labrosus), golden grey mullet (Liza aurata), thin lip mullet (Liza ramada) and flathead mullet (Mugil cephalus) (Pisces: Mugilidae) from different Adriatic sites: meristic counts and skeletal anomalies. Ecological Indicators, 6(4): 712732.

Boglione C, Gagliardi F, Scardi M \& Cataudella S (2001). Skeletal descriptors and quality assessment in larvae and post-larvae of wild-caught and hatchery-reared gilthead sea bream (Sparusaurata L. 1758). Aquaculture, 192(1): 1-22.

Brain FD \& Amy C (1980). Induced Fish Breeding in South East Asia. Report of the Workshop held in Singapore. International Development Research Centre, Ottawa Canada. Pp 17-20.

Brander GC \& Pugh DM (1977). Veterinary Applied Pharmacology and Therapeutics. Third edition, The English Language Book Society and Bailliere Tindall, London. Pp 536.

Castro J, Pino-Querido A, Hermida M, Chavarrias D, Romero R, Garcia-Cortes LA, Toro MA \& Martinez P (2008). Heritability of skeleton abnormalities (lordosis, lack of operculum) in gilthead seabream (Sparus aurata) supported by microsatellite family data. Aquaculture, 279(1-4): 18-22.

Chatain B (1994). Estimation et amélioration des performances zootechniques de l'élevage larvaire de Dicentrarchus labraxet de Sparusauratus. Doctorat d'état, Universitéd’Aix-Marseille II. Pp 199. 
Dabrowski K (2001). Ascorbic acid in aquatic organisms: status and Perspectives. CRC Press, Boca Raton, FL. Pp 13.

De Graaf G \& Janssen H (1996). Artificial reproduction and pond rearing of the African catfish, Clarias gariepinus in subSaharan Africa- A Handbook. FAO Fisheries Technical Paper, No 362. Pp 73.

Dunham RA, Smitherman RO \& Bondari K (1991). Lack of inheritance of stumpbody and taillessness in channel catfish. The Progressive Fish-Culturist, 53(2): 101-105.

Eickemeyer (2005). Operating Manual for High Frequency X-ray Unit. Hiray Plus, Vet Eicker meyer. Tuttlingen, Germany. Pp 11.

Fagbenro OA \& Sydenham DHJ (1988). Evaluation of Clarias isheriensis (Sydenham) under semiintensive management in ponds. Aquaculture, 74(3-4):287-291

Fagbuaro O (2009). Inbreeding of mouth malformed and crocked back Clarias gariepinus. Journal of Agricultural Science and Technology, 3(12): $44-50$.

Fagbuaro 00 \& Oso JA (2011). Skeletal malformations among the Clarias species from fish mongers in Ekiti State. Continental Journal of Fisheries and Aquatic Science, 5(2): $32-37$.

FAO (2012). Clarias gariepinus Burchell,1822. Cultured Aquatic Species Information Programme. Fisheries and Aquaculture Department, Food and Agricultural Organization of the UN. Pp 5.

Jawad LA (2004). First record of anomalies in mullet fish (Mugil cephalus) from New Zealand. Tuhinga, 15: $121-124$.

Komada N \& Moyer JT (1983). Spinal curvature in the carangid fish Seriola aureoviattata from Miyakejima, Japan. Japan Journal of Ichthyology, 30(2): 185 - 192.

Korwin-Kossakowski M (1988). Larval development of carp, Cyprinus carpio in acidic water. Journal of Fish Biology, 32(1): 17-26.

Legendre M, Teugels GG, Cauty C \& Jalabert B (1992). A comparative study on morphology, growth rate and reproduction of Clarias gariepinus (Burchell, 1822), Heterobranchus longifilis Valenciennes, 1840, and their reciprocal hybrids (Pisces, Clariidae). Journal of Fish Biology, 40(1): 5979.
Lovell RT (1973). Essentiality of vitamin C in feeds for intensively fed caged channel catfish. The Journal of Nutrition, 108(1): 134-138.

Madu CT, Ita EO, Omorinkoba WS \& Pandogari A (1989). Induced spawning technique of mudfish Clarias anguillaris (L). NIFFR Technical Report Series, 17: 2-8.

Madu CT, Okwuego CC \& Madu ID (2003). Optimum dietary protein level for growth and gonadal maturation of female Heterobranchus longifilis (Valenciennes, 1840) broodstock. Journal of Aquatic Sciences, 18(1): 29-34.

Makeeva AP \& Saha JN (1985). Cytological study of the ovulated oocytes and embryo during artificial reproduction of silver carp and white amur. Biologicheskie Nauki, 7:38-43.

Muir JF (1984). Water quality and aquaculture systems. In: Disease and Health Control of Farmed Fish (including Shellfish and Crustaceans) in Europe. FAO, Fiat Paris. Pp 235.

Netting R (2007). X-Rays. National Aeronautics and Space Administration (NASA). http://missionscience.nasa.gov/ems/11-xrays.html, retrieved 05-07-2012.

Offem BO, Ayotunde EO \& Ukpi GU (2008). Dynamics in the reproductive biology of Heterobranchus longifilis Val, (Pisces: 1840) in the inland wetlands of Cross river, Nigeria. Research Journal of Fisheries and Hydrobiology, 3(1): 22-31.

Offem BO, Ikpi GU \& Ayotunde EO (2009). Effect of stocking size of the predatory African catfish (Heterobranchus longifilis) on the growth performance of Nile Tilapia (Oreochromis niloticus L.) in pond culture. International Journal of Fisheries and Aquaculture, 1(3): 38-43.

Oladosu GA, Ayinla OA, Adeyemo AF, Yakubu AF \& Ajani AA (1993). A comparative study of the reproductive capacity of the African catfish species Heterobranchus bidorsalis Geoffrey, Clarias gariepinus Burchell and their hybrid "Heteroclarias" Nigerian Institute for Oceanography and Marine Research Technical Paper, No. 92.

Olubiyi OO, Ayinla OA \& Adeyemo AA (2005). The effects of various doses of ovaprim on reproductive performance of the African catfish Clarias gariepinus (Burchell) and Heterobranchus longifilis (Valenciennes). 
African Journal of Applied Zoology and Environmental Biology, 7(1): 101-105.

Ovie SO, Ovie SI \& Madu A (2008). Growth and survival of Heterobranchus longifilis fry at different stocking densities. The Zoologist, 6(1): 21-26.

Owodeinde FG, Ndimele PE \& Anetekhai MA (2011). Reproductive growth performance and nutrient utilization of Heterobranchus bidorsalis (Geoffroy, 1809) and its hybrid 'Clariabranchus' induced with synthetic hormone and pituitary gland of Heterobranchus bidorsalis. International Journal of Zoological Research, 7(5): 345357.

Poncin P, Petitfrere P, Vanderwalle P \& Ruwet JC (2002). The reproductive behaviour of the African catfish Heterobranchus longifilis (Siluriformes, Clariidae) in an aquarium preliminary results. Belgian Journal of Zoology, 132(1): 35-39.

Richter CJJ \& Van der Hurk R (1982). Effects of 11desoxycorticosterone-acetate and carp pituitary suspension on follicle maturation in the ovaries of the African catfish, Clarias lazera (Cuvier and Valenciennes). Aquaculture, 29(1): 53-66.

Rodriguez NJ, Oteme ZJ \& Hem S (1995). Comparative study of vitellogenesis of two African catfish species Chrysichthys nigrodigitatus (Claroteidae) and
Heterobranchus longifilis (Clariidae). Aquatic Living Resources, 8(4): 291-296.

Sahoo SK, Giri SS \& Sahoo AK (2005). Induced spawning of Asian catfish $C$. batruchus (Linn): effect of various latency periods and SGnRHa and domperidone doses on spawning performance and egg quality. Aquaculture Resources, 36(13): 1273.

Teugels GG, Ozouf-costaz C, Legendre M \& Parrent $M$ (1992). A karyological analysis of the artificial hybridization between Clarias gariepinus (Burchell, 1822) and Heterobranchus longifilis Valenciennes, 1840 (Pisces: Clariidae). Journal of Fish Biology, 40(1): 81-86.

Vandewalle P, Gluckmann I, Baras E, Huriaux F \& Focant B (1997). Postembryonic development of the cephalic region in Heterobranchus longifilis. Journal of Fish Biology, 50(2): 227-253.

Wang X, Kanggwoong K \& Sungchul CB (2002). Effects of different dietary levels of Lascorbyl-2-polyphosphate on growth and tissue vitamin $C$ concentrations in juvenile olive flounder, Paralichthys olivaceus (Temmincket Schlegel). Aquacultural Resources, 33(4): 261-267.

Wilson RP \& Poe W E (1973). Impaired collagen formation in the scorbutic channel catfish. Journal of Nutrition, 103(9): 1359-1364. 